\title{
Enhancement of Antiviral Activity of Collectin Trimers through Cross-Linking and Mutagenesis of the Carbohydrate Recognition Domain
}

\author{
Mitchell R. White ${ }^{a}$ Patrick Boland ${ }^{a}$ Tesfaldet Tecle ${ }^{a}$ Donald Gantz ${ }^{b}$ \\ Grith Sorenson $^{d}$ Ida Tornoe ${ }^{d}$ Uffe Holmskov ${ }^{d}$ Barbara McDonald ${ }^{c}$ \\ Erika C. Crouch ${ }^{c}$ Kevan L. Hartshorn ${ }^{a}$ \\ Departments of a Medicine and ${ }^{b}$ Biophysics, Boston University School of Medicine, Boston, Mass., and \\ 'Department of Pathology and Immunology, Washington University School of Medicine, St. Louis, Mo., USA; \\ ${ }^{\mathrm{d}}$ Department of Immunology and Microbiology and Medical Biotechnology Center, Institute of Medical Biology, \\ University of Southern Denmark, Odense, Denmark
}

\section{Key Words}

Influenza virus $\cdot$ Surfactant protein D $\cdot$ Neutrophils

\begin{abstract}
Surfactant protein D (SP-D) plays important roles in innate defense against respiratory viruses [including influenza A viruses (IAVs)]. Truncated trimers composed of its neck and carbohydrate recognition domains (NCRDs) bind various ligands; however, they have minimal inhibitory activity for IAV. We have sought to find ways to increase the antiviral activity of collectin NCRDs. Cross-linking of the SP-D NCRD with nonblocking monoclonal antibodies (mAbs) markedly potentiates antiviral activity. In the present report, we demonstrate that $F\left(a b^{\prime}\right) 2$ [but not $F\left(a b^{\prime}\right) 1$ ] fragments of a crosslinking $\mathrm{mAb}$ have similar effects. Hence, cross-linking activity, but not the Fc domain of the $\mathrm{mAb}$, is needed for increased antiviral activity. In contrast, the Fc domain of the mAb was important for increasing viral uptake or respiratory burst responses of human neutrophils. Our NCRD constructs contain an $\mathrm{S}$ protein binding site. Herein, we show that a multivalent $\mathrm{S}$ protein complex caused cross-linking and also increased the antiviral activity of NCRDs. NCRDs of conglutinin and CL43 had greater intrinsic antiviral activity than those of
\end{abstract}

SP-D or mannose-binding lectin. Based on motifs found in these serum collectins, we have constructed mutant versions of the human SP-D NCRD that have increased antiviral activity. These mutant NCRDs also had potentiated activity after cross-linking with $F\left(a b^{\prime}\right) 2$ fragments or $S$ protein complexes. Hence, the antiviral activity of NCRDs can be increased by 2 distinct, complementary strategies, namely cross-linking of NCRDs through various means and mutagenesis of CRD residues to increase viral binding. These findings may be relevant for antiviral therapy.

Copyright $\odot 2009$ S. Karger AG, Basel

\section{Introduction}

Surfactant collectins, including surfactant protein A and surfactant protein D (SP-D), play important roles in host defense against influenza A virus (IAV) and other pathogens [1]. The collectins are composed of 4 domains including an $\mathrm{N}$ terminus, a collagen domain, a neck domain and a carbohydrate recognition domain (CRD). The basic structural unit of the collectin is a trimer [2]. These trimers in most cases assemble into larger multimeric assemblies through disulfide bond formation at the

\section{KARGER}

Fax +41613061234

E-Mail karger@karger.ch

www.karger.com (c) 2009 S. Karger AG, Basel

Accessible online at: www.karger.com/jin
Dr. Kevan L. Hartshorn

Department of Medicine, Section of Hematology/Oncology Boston University School of Medicine

EBRC 414, 650 Albany Street, Boston, MA 02118 (USA)

Tel. +1 617638 5638, Fax +1 617638 7530, E-Mail khartsho@bu.edu 
$\mathrm{N}$ terminus. Through extensive studies with SP-D, we have shown that the level of oligomerization has an important impact on antiviral activity [3-5]. SP-D most commonly forms dodecamers (with 4 trimers together making a cross-like structure). Human SP-D can also be present in vivo and in vitro as full-length trimers or highmolecular weight multimers ( $\geq 32$ trimers per molecule). Dodecamers and multimers have greater antiviral activity than trimers. The neck domain of collectins mediates trimerization, and recombinant preparations containing just the neck and CRD (NCRD) of collectins spontaneously trimerize and have lectin activity.

NCRD preparations of human SP-D (hNCRD) are being explored as therapeutics because they are relatively easy to produce in bacteria and have beneficial activity in various in vitro or murine model systems [6-10]. For instance, hNCRD can restore some functions of SP-D-/mice and can ameliorate respiratory syncitial virus infection or pulmonary hypersensitivity reactions. It should be noted that many of these studies employed an NCRD construct that also contains a short $\mathrm{N}$-terminal collagen domain fragment which has impact on its activity [11]. We have explored the activities of the human SP-D NCRD with regard to IAV, using an NCRD without any collagen sequence but with an S protein binding site and His tag in the $\mathrm{N}$ terminus [12]. Unfortunately, these human SP-D NCRD trimers have minimal ability to bind IAV and greatly reduced antiviral activity compared to full-length SP-D. We have shown, however, that cross-linking hNCRDs with certain monoclonal antibodies (mAbs) directed against SP-D results in strong antiviral activity [3]. In addition, mutations introduced around the lectin site of the CRD confer antiviral activity on hNCRD without the need for cross-linking $[12,13]$.

The goals of the current project were to understand the mechanisms through which $\mathrm{mAbs}$ enhance the antiviral activity of NCRDs. Firstly, we wanted to determine if the $\mathrm{Fc}$ domain on the $\mathrm{mAbs}$ are needed to enhance specific functional activities of NCRDs. To this end, we evaluated the effectiveness of Fab fragments of an enhancing $\mathrm{mAb}$ in combination with wild-type SP-D NCRD. We also wanted to develop alternative methods of cross-linking of NCRDs so that we could directly compare the activity of NCRDs of various collectins after cross-linking, to confirm increased intrinsic antiviral activity of the NCRDs of some of the serum collectins. We achieved this using a multivalent preparation of S protein and a panel of collectin NCRDs all containing the $S$ protein binding site. In this way we established a hierarchy of antiviral activity among wild-type collectin NCRDs as follows:
CL43 > conglutinin > mannose binding-lectin (MBL) or SP-D. Finally, we wanted to determine if mutant versions of the human SP-D NCRD with increased antiviral activity would show a further increase in activity after crosslinking. In particular, the serum collectins all have a hydrophobic amino acid (valine or isoleucine) at position 343 (using SP-D numbering), whereas SP-D and surfactant protein A have arginine or lysine (for rodent SP-D) at this site. Human SP-D NCRDs containing R343V or R343I substitutions have increased antiviral activity compared to the NCRD of wild-type SP-D [13]. We now show that cross-linking of these mutants with either $\mathrm{mAbs}$ or $\mathrm{S}$ protein complexes caused a further marked increase in antiviral activity. Of note, the antiviral activity of R343V cross-linked with S protein complexes exceeded that of any of the wild-type collectin NCRDs treated in a similar manner.

\section{Materials and Methods}

\section{Virus Preparations}

IAV was grown in the chorioallantoic fluid of 10-day-old chicken eggs and purified on a discontinuous sucrose gradient as previously described [14]. The virus was dialyzed against PBS to remove sucrose, aliquoted and stored at $-80^{\circ} \mathrm{C}$ until needed. Philippines 82/H3N2 (Phil82) and its bovine serum inhibitor resistant variants (Phil82/BS) were kindly provided by Dr. E. Margot Anders (University of Melbourne, Melbourne, Australia). After thawing, the viral stocks contained approximately $5 \times 10^{8}$ plaque-forming units/ml. The Phil82/BS strain is relatively resistant to collectins and other lectins with affinity for mannose like cyanovirin [15].

\section{Collectin Preparations}

Dodecamers of wild-type recombinant human SP-D were used as a control preparation and expressed in $\mathrm{CHO}$ cells and purified as described elsewhere [16]. NCRD preparations, including the wild-type human NCRD (hNCRD), rat NCRD (rNCRD), NCRDs of MBL, conglutinin and CL43 and of the R343V and R343I mutants, were produced in E. coli as described elsewhere [12, 17]. The use of bacterially expressed proteins is feasible because there are no known post-translational modifications within the human SP$\mathrm{D}$ CRD or neck domains, which self-assemble in vitro as stable trimers with lectin activity. All of the NCRD preparations contain an $\mathrm{S}$ protein binding site in the $\mathrm{N}$ terminus as described previously [17]. Sequences were verified by automated sequencing of the entire coding sequence of the fusion protein. RosettaBlue competent cells were transformed with the wild-type or mutant construct in $\mathrm{pET}-30 \mathrm{a}(+)$ vector, and expressed proteins were isolated from inclusion bodies. After refolding and oligomerization, the fusion proteins were purified by nickel affinity chromatography. Trimers were isolated by gel filtration chromatography on an Äkta system (24). All proteins were isolated in similar yields with similarly low levels of endotoxin ( 0.1 to approximately $0.5 \mathrm{EU} / \mathrm{ml}$; Limulus Lysate Assay, Cambrex, Walkersville, Md., USA). The fusion 
proteins showed the expected mobility on SDS-PAGE in the absence and presence of sulfhydryl reduction, as previously demonstrated for the wild-type protein [12].

The R343V and R343I mutants used in the current study form trimers like wild-type SP-D NCRD and they only differ in the single noted amino acid substitution $[13,18]$. To produce R343V and R343I, site-directed mutagenesis was performed using a QuikChange II XL Site-Directed Mutagenenesis Kit (200521, Stratagene, La Jolla, Calif., USA) and the human SP-D neck + CRD DNA as template.

\section{Monoclonal Antibodies}

mAbs 246-04 and 246-08 were raised against SP-D by inoculating mice with $10 \mu \mathrm{g} / \mathrm{ml}$ human SP-D as previously described [19]. Both of these mAbs bind to the NCRD of human SP-D although neither blocks binding of SP-D to mannan or IAV [20]. The Fab fraction of Hyb 246-08 was obtained by proteolysis of the whole immunoglobulins by papain (Sigma-Aldrich, Brøndby, Denmark). Antibody was dialyzed into $100 \mathrm{~mm} \mathrm{NaOAc}, \mathrm{pH} 5.5$, and $1 \mathrm{~mm}$ EDTA. Papain and antibody were mixed together at a ratio of 1:100 by weight. The antibodies $(1.5 \mathrm{mg})$ and papain $(15 \mu \mathrm{g})$ were dissolved in $1.5 \mathrm{ml}$ of $100 \mathrm{~mm} \mathrm{NaOAc}$, pH 5.5, containing $1 \mathrm{~mm}$ EDTA and $50 \mathrm{mM}$ cysteine. The solution was incubated at $37^{\circ} \mathrm{C}$ for $5 \mathrm{~h}$. The degree of formation of Fab fragments was monitored by SDS-PAGE after size selection using a Superdex 200 column (GE Healthcare, Brøndby, Denmark). F(ab')2 fragments were prepared using pepsin, as follows. Firstly, $2 \mathrm{mg}$ of purified Hyb 246-08 (batch 040889) was digested with pepsin. After initial buffer exchange into $100 \mathrm{~mm}$ acetate buffer (pH 4.5) using an Äkta HiTrap Fast Desalting column, 3\% (w/w) pepsin (P6887, Sigma-Aldrich) was added to the immunoglobulin solution. IgG was then incubated overnight at $37^{\circ} \mathrm{C}$ and the fragments were eluted in TBS, pH 7.4 , and $0.05 \% \mathrm{NaN}_{3}$ by size fractionation with an Äkta Superdex 200 column. Pepsin cleavage yielded F(ab')2 fragments with an apparent molecular weight of $110 \mathrm{kDa}$ as judged by SDS-PAGE.

\section{Hemagglutination Inhibition Assay}

Hemagglutination (HA) inhibition was measured by serially diluting collectins or other host defense protein preparations in round-bottom 96-well plates (Serocluster U-Vinyl plates, Costar, Cambridge, Mass., USA) using PBS containing calcium and magnesium as a diluent [21]. After adding $25 \mu \mathrm{l}$ of IAV, giving a final concentration of $40 \mathrm{HA}$ units/ml or $4 \mathrm{HA}$ units/well, the IAV-protein mixture was incubated for $15 \mathrm{~min}$ at room temperature, followed by addition of $50 \mu \mathrm{l}$ of a type $\mathrm{O}$ human erythrocyte suspension. The minimum concentration of protein required to fully inhibit the hemagglutinating activity of the viral suspension was determined by noting the highest dilution of protein that still inhibited HA. Inhibition of HA activity in a given well is demonstrated by the absence of formation of an erythrocyte pellet. If no inhibition of HA activity was observed at the highest protein concentration used, then the value is expressed as being greater than the maximal protein concentration. For some experiments, the NCRDs were first preincubated with $S$ protein, $S$ protein-biotin or S protein-horseradish peroxidase (HRP) conjugate. The S protein preparations were purchased from Novagen.

Measurement of Viral Aggregation by Collectins

Viral aggregation was measured by assessing light transmission through stirred suspensions of IAV as previously described
[22]. In addition, viral aggregates were visualized using electron microscopy as described elsewhere [23].

ELISA Assay for Measurement of Binding of NCRDs to IAV Binding of trimeric NCRD fusion proteins to IAV was measured as previously described using the $S$ protein-HRP conjugate [12]. In brief, ELISA plates were coated with virus followed by washing and addition of NCRD alone or NCRD that had been preincubated with $S$ protein-HRP. After further washing, S protein-HRP was added to the wells that had only received NCRD. Binding was detected using peroxidase substrate (Pierce, Rockford, Ill., USA). All values are given as the mean \pm standard error of the mean (SEM) of at least 3 independent experiments.

\section{Fluorescent Focus Assay of IAV Infectivity}

MDCK cell monolayers were prepared in 96-well plates and grown to confluency. These layers were then infected with diluted IAV preparations for $45 \mathrm{~min}$ at $37^{\circ} \mathrm{C}$ in $\mathrm{PBS}$ and tested for the presence of IAV-infected cells after $7 \mathrm{~h}$ using an $\mathrm{mAb}$ directed against the influenza A viral nucleoprotein (provided by Dr. Nancy Cox, CDC, Atlanta, Ga., USA) as previously described [24]. IAV was preincubated for $30 \mathrm{~min}$ at $37^{\circ} \mathrm{C}$ with SP-D or control buffer, followed by addition of these viral samples to the MDCK cells. Where indicated, SP-Ds were first incubated with $\mathrm{mAbs}$ prior to adding them to IAV.

\section{Human Neutrophil Preparation}

Neutrophils from healthy volunteers were isolated to $>95 \%$ purity using dextran precipitation, followed by Ficoll-Paque gradient separation for the removal of mononuclear cells and then hypotonic lysis to eliminate any contaminating erythrocytes, as previously described [14]. Cell viability was determined to be $>98 \%$ by trypan blue staining. The isolated neutrophils were resuspended at the appropriate concentrations in control buffer (PBS) and used within $2 \mathrm{~h}$. Neutrophil collection was performed with informed consent as approved by the Institutional Review Board of the Boston University School of Medicine. RAW 264.7 cells were obtained from the American Type Culture Collection (Manassas, Va., USA).

\section{Measurement of IAV Uptake by Neutrophils}

Fluorescein isothiocyanate (FITC)-labeled IAV (Phil82 strain) was prepared, and uptake of virus by neutrophils was measured by flow cytometry as described elsewhere $[22,25]$. In brief, IAV was incubated with neutrophils for $30 \mathrm{~min}$ at $37^{\circ} \mathrm{C}$ in the presence of control buffer. Trypan blue $(0.2 \mathrm{mg} / \mathrm{ml})$ was added to these samples to quench extracellular fluorescence. Following washing, the neutrophils were fixed with paraformaldehyde and neutrophil-associated fluorescence was measured using flow cytometry. The mean neutrophil fluorescence $(>1,000$ cells counted per sample) was measured.

\section{Measurement of Neutrophil $\mathrm{H}_{2} \mathrm{O}_{2}$ Production}

$\mathrm{H}_{2} \mathrm{O}_{2}$ production was measured by assessing the reduction in scopoletin fluorescence as previously described [26]. Measurements were made using a Polarstar Optima fluorescent plate reader (BMG Labtech, Durham, N.C., USA). Using this assay, a decrease in fluorescence occurs with the production of $\mathrm{H}_{2} \mathrm{O}_{2}$. 


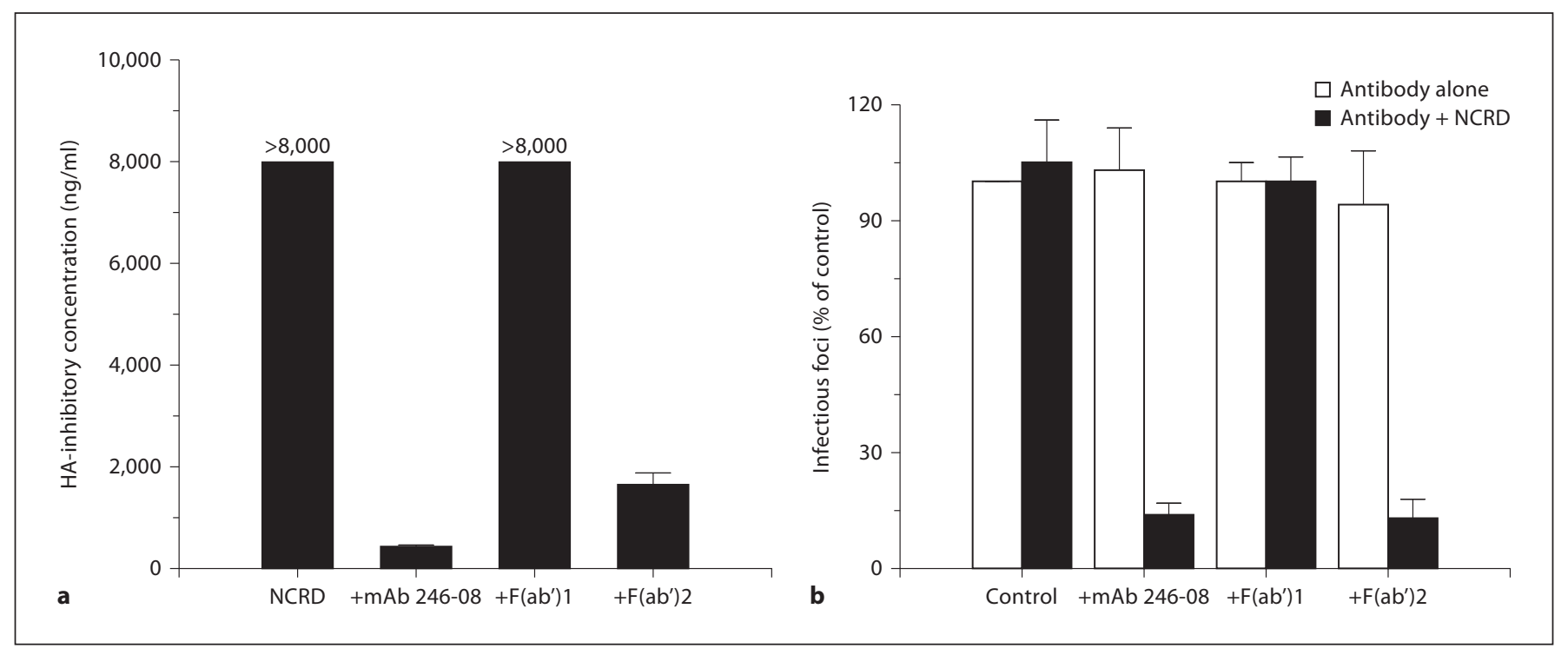

Fig. 1. $\mathrm{F}(\mathrm{ab}) 2$ fragments of the $246-08 \mathrm{mAb}$ potentiate HA inhibition and viral neutralization by the human SP-D NCRD (NCRD). Aliquots of the Phil82 strain of IAV were preincubated with NCRD alone or NCRD combined with the intact 246-08 antibody to SP-D or F(ab')1 or F(ab')2 fragments of that antibody. Then the effects of these treatments on viral HA activity (a) and viral infectivity for MDCK cells (b) were tested. Results are means \pm SEM of 3 or more experiments. a NCRD alone at concentrations up to $8 \mu \mathrm{g} / \mathrm{ml}$ did not cause any inhibition of HA activity. Addition of

\section{Statistics}

Statistical comparisons were made using Student's paired, two-tailed t test or ANOVA with a post hoc test (Tukey's). ANOVA was used for multiple comparisons to a single control.

\section{Results}

Role of Fc Domain and Bivalency in the Ability of $m A b s$ to Increase Antiviral Activity of hNCRD

As shown in figure 1, the 246-08 $\mathrm{mAb}$ and its $\mathrm{F}(\mathrm{ab}$ ')2 fragments had nearly equivalent ability to increase HA inhibition and the viral neutralizing activity of wild-type $\mathrm{hNCRD}$. This indicates that the Fc domain of the $\mathrm{mAb}$ is not needed for these activities. In contrast, $F(a b$ ') 1 fragments of the $\mathrm{mAb}$ were without activity, indicating that bivalency and the cross-linking ability of the mAb are crucial for increasing antiviral activity.

\section{Role of Fc Domain and Bivalency in the Ability of $m A b s$ to Increase Neutrophil or Macrophage Uptake of IAV}

As shown in figure 2, $\mathrm{F}(\mathrm{ab}$ ') 2 but not $\mathrm{F}(\mathrm{ab}$ ') 1 fragments of the 246-08 mAb significantly increased uptake of IAV
$\mathrm{F}\left(\mathrm{ab} \mathrm{b}^{\prime}\right) 1$ fragments did not alter this results; however, addition of the intact $\mathrm{mAb}$ or $\mathrm{F}(\mathrm{ab}) 2$ fragments of the $\mathrm{mAb}$ did result in $\mathrm{HA}$ inhibition $(\mathrm{p}<0.05)$. b Similarly, NCRD alone $(12 \mu \mathrm{g} / \mathrm{ml})$ or combined with $\mathrm{F}(\mathrm{ab}$ ')1 fragments had no viral neutralizing activity, whereas the intact $\mathrm{mAb}$ or $\mathrm{F}\left(\mathrm{ab}^{\prime}\right) 2$ fragments caused significant inhibition (each was significantly less than control or NCRD alone as assessed by ANOVA). The mAb alone had no effect on viral infectivity (black bar in Control).

by neutrophils and RAW cells. In the case of neutrophils, the intact antibody had a greater effect on uptake than $\mathrm{F}(\mathrm{ab}$ ')2 fragments, suggesting that the Fc domain may engage neutrophil receptors and promote viral uptake to a greater extent than $\mathrm{F}(\mathrm{ab}$ ') 2 fragments alone. In the case of RAW cells, there was no difference between the effects of $\mathrm{F}(\mathrm{ab}$ ')2 fragments and intact antibody. We previously reported that treatment of IAV with hNCRD cross-linked by the mAb 246-08 markedly increases neutrophil $\mathrm{H}_{2} \mathrm{O}_{2}$ responses to the virus. As shown in figure $2 c$, the addition of $\mathrm{F}(\mathrm{ab}$ ') 2 to hNCRD did not significantly potentiate the neutrophil $\mathrm{H}_{2} \mathrm{O}_{2}$ responses elicited by IAV plus hNCRD. Note that the scopoletin assay for $\mathrm{H}_{2} \mathrm{O}_{2}$ generation involves quenching of scopoletin fluorescence by $\mathrm{H}_{2} \mathrm{O}_{2}$, so that increased $\mathrm{H}_{2} \mathrm{O}_{2}$ generation is reflected in decreased fluorescence.

\section{Multivalent S Protein Increases Viral Binding and Antiviral Activity of NCRDs}

We wanted to develop an additional means of crosslinking NCRDs to confirm the findings obtained with $\mathrm{F}(\mathrm{ab}$ ')2 fragments and to be able to compare activities of various mammalian NCRDs that do not bind mAbs di- 


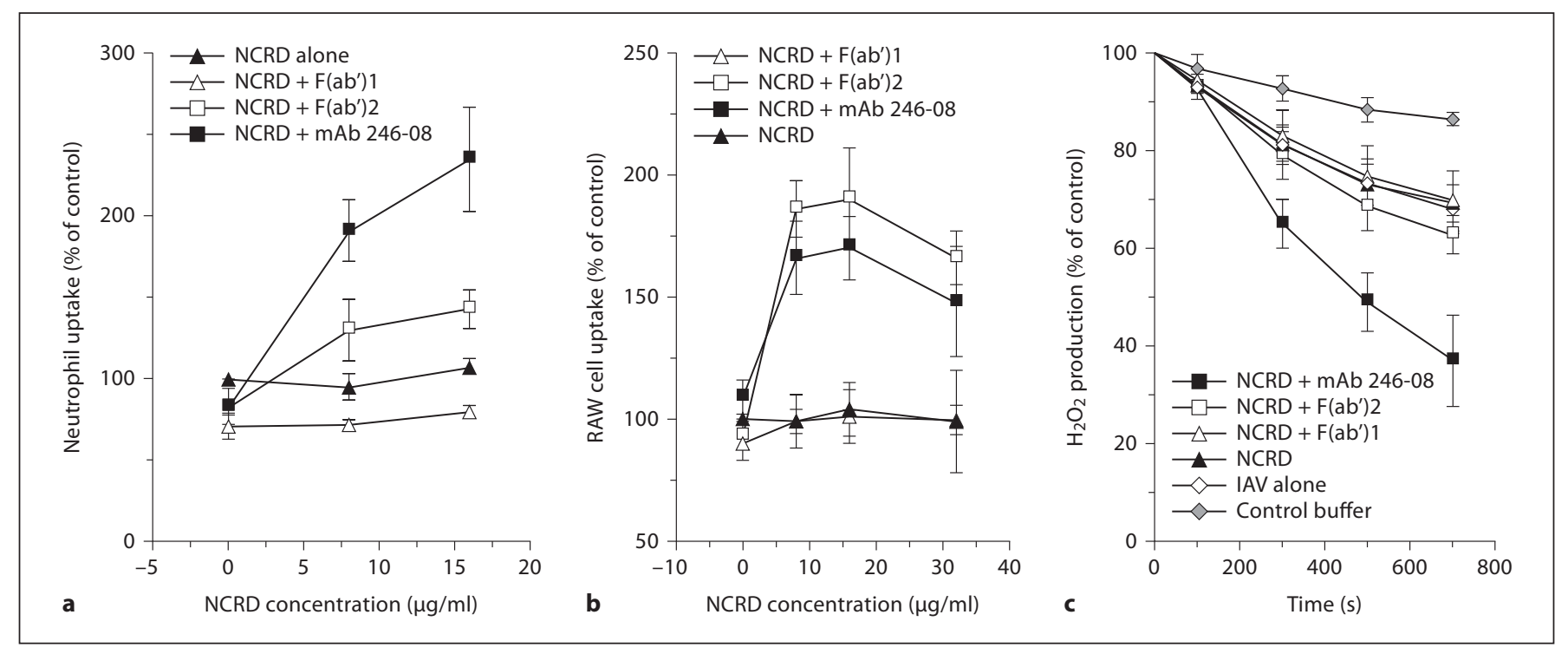

Fig. 2. a, b F(ab')2 fragments of the 246-08 mAb allow hNCRD to promote neutrophil or RAW 264.7 cell uptake of IAV. FITC-labeled IAV was preincubated with hNCRD alone (at the indicated concentrations), or hNCRD combined with mAb 246-08 or the $\mathrm{F}(\mathrm{ab}) 1$ or $\mathrm{F}(\mathrm{ab}$ ') 2 fragments of the $\mathrm{mAb}$, and these samples were then incubated with either human neutrophils (a) or murine RAW 264.7 cells (b). Viral uptake was measured by flow cytometry as described in Materials and Methods. Results are means \pm SEM of 5 or more experiments (using separate neutrophil donors in a). NCRD alone did not significantly increase viral uptake by neutrophils or RAW 264.7 cells. The intact $\mathrm{mAb}$ and the F(ab')2 fragments increased neutrophil and RAW cell uptake when combined

rected against human SP-D. Our NCRDs contain an S protein binding site which we exploited for this purpose. $S$ protein conjugated with HRP can be used to detect binding of our NCRDs to various ligands. Previous binding studies have shown that different NCRD preparations are equivalently detected by the $S$ protein-HRP conjugates. As shown in figure $3 \mathrm{a}, \mathrm{S}$ protein-HRP is present as high-molecular weight aggregates on a nonreduced SDSPAGE gel, whereas free S protein or S protein conjugated to biotin exist as monomers. This property of $S$ proteinHRP was exploited for our studies to generate aggregates of NCRDs containing the $S$ protein binding site. As shown in figure $3 \mathrm{~b}$, preincubation of hNCRD with the S proteinHRP complex resulted in substantially increased binding to IAV compared to the situation where hNCRD is added to the virus followed by addition of $S$ protein-HRP. This implies that $S$ protein-HRP forms a complex with hNCRD that is able to bind more avidly to IAV by presenting multiple hNCRD trimeric heads simultaneously (resembling an SP-D multimer). Preincubation of either hNCRD or with hNCRD $(\mathrm{p}<0.03)$. The mAb and Fab fragments alone did not alter uptake of IAV (data not shown). In the case of neutrophils (but not in the case of RAW cells), the effect of the intact $\mathrm{mAb}$ on viral uptake was significantly greater than that of $\mathrm{F}(\mathrm{ab}$ ') 2 when assessed by ANOVA. F(ab')1 fragments did not increase viral uptake, either alone or in combination with NCRD. c Neutrophil $\mathrm{H}_{2} \mathrm{O}_{2}$ responses. IAV alone caused significantly greater $\mathrm{H}_{2} \mathrm{O}_{2}$ responses than those seen in cells incubated with control buffer alone $(n=3$; $\mathrm{p}<0.05)$. Adding hNCRD or hNCRD + F(ab')1 or F(ab')2 fragments did not significantly increase the $\mathrm{H}_{2} \mathrm{O}_{2}$ response compared to IAV alone when assessed by ANOVA. In contrast, hNCRD + intact $\mathrm{mAb}$ did significantly increase the response.
rNCRD with S protein-HRP also allowed the NCRDs to inhibit viral HA activity (fig. 4a). Preincubation with free $S$ protein or S protein-biotin did not confer HA-inhibiting activity. These preparations provide useful controls because (as demonstrated in fig. 3a) they are not multimeric complexes of $S$ protein.

The results indicate that multivalency is required for $\mathrm{S}$ protein to potentiate the antiviral activity of NCRDs. The $S$ protein-HRP conjugate was also able to potentiate the viral neutralizing activity of hNCRD (fig. 4b), conferred viral aggregating activity on hNCRD (fig. 5a) and allowed the hNCRD to increase neutrophil and RAW cell uptake of IAV (fig. 5b). This again suggests that increased phagocyte uptake of IAV can occur in the absence of N-terminal domains of collectins or the Fc domain of antibodies as long as viral aggregation occurs. Note that viral aggregation was measured by assessing light transmission through stirred suspensions of IAV in this assay, and viral aggregates reduce light transmission compared to untreated virus [21]. Samples treated in the same manner as for the 


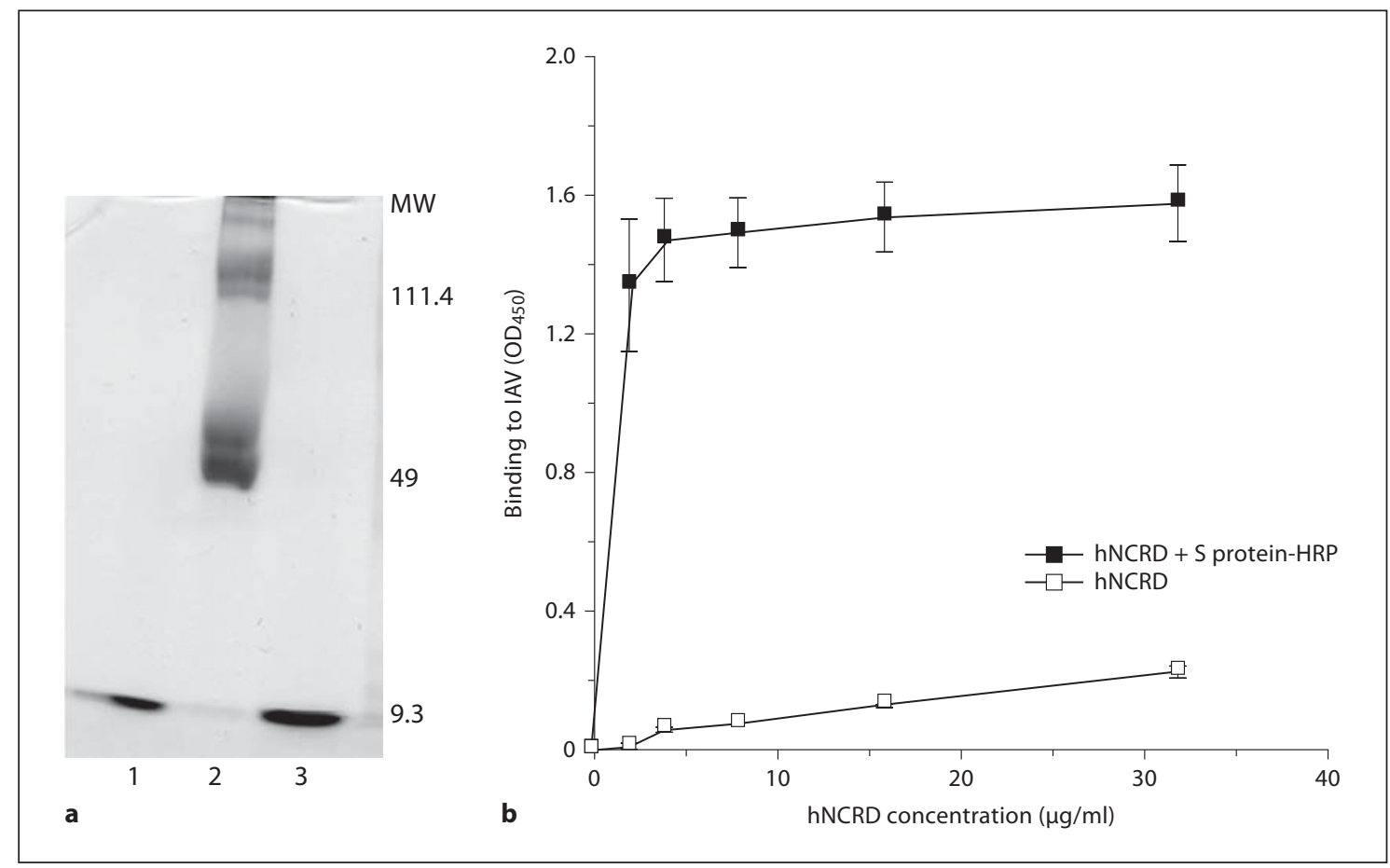

Fig. 3. $S$ protein-HRP is present as aggregates of $S$ protein and increases binding of hNCRD to IAV. a A nonreduced SDS-PAGE gel of S protein-HRP, free S protein, or S protein-biotin. The latter two preparations are in monomeric form, whereas the $S$ protein$\mathrm{HRP}$ is present as large aggregates of approximately 50 or 100 $\mathrm{kDa}$. Lane 1: S protein $(1 \mu \mathrm{g})$; lane 2 : S protein-HRP $(1 \mu \mathrm{g})$; lane
3: S protein-biotin $(1 \mu \mathrm{g})$. b Preincubation of hNCRD with S protein-HRP markedly increased binding of hNCRD to IAV as assessed by ELISA ( $n=3 ; \mathrm{p}<0.01$ at all concentrations of hNCRD). Free $\mathrm{S}$ protein did not increase viral aggregation in response to hNCRD (data not shown).

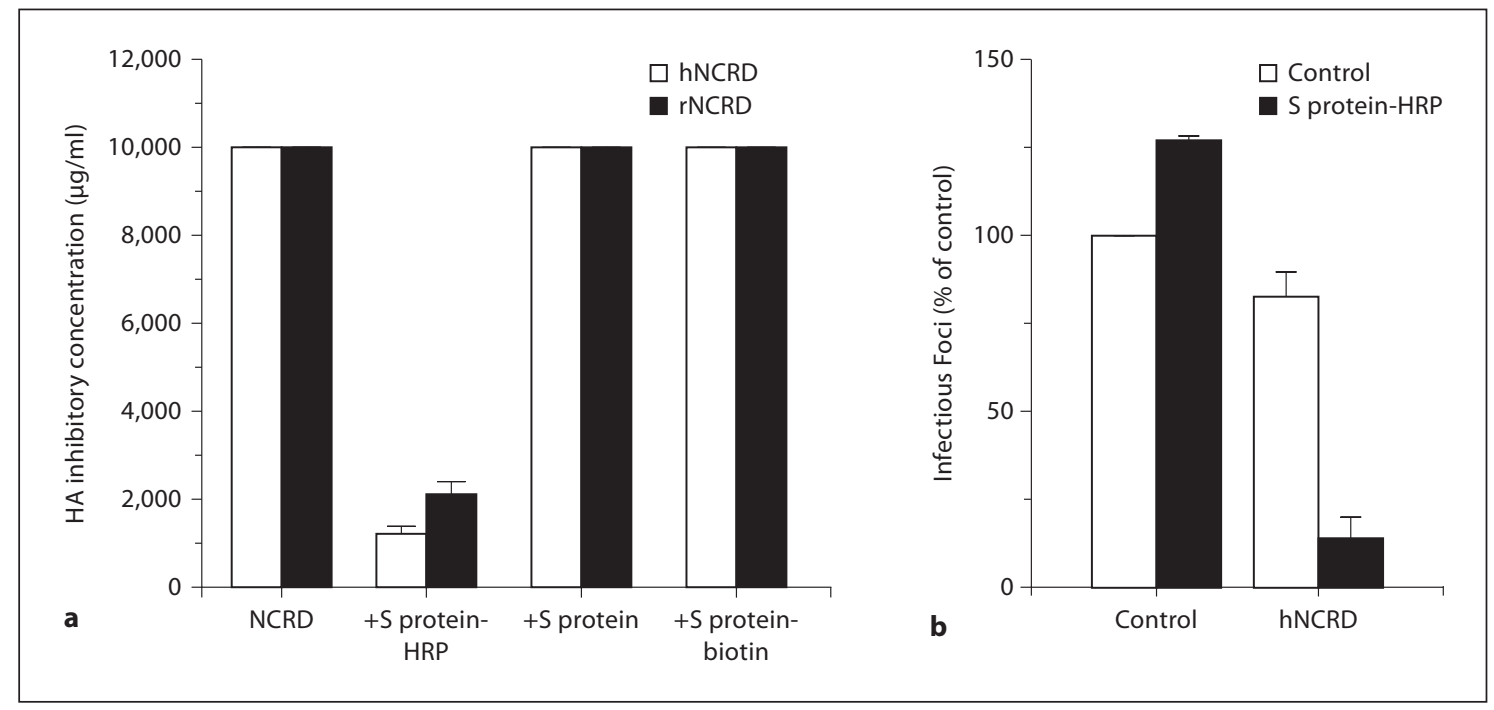

Fig. 4. Addition of $S$ protein-HRP to hNCRD allows it to inhibit viral HA activity and cause viral neutralization. The experiments were performed as in figure 1 except that $S$ protein-HRP, free $S$ protein or $S$ protein-biotin were incubated with hNCRD instead of antibody fragments. S protein-HRP enabled hNCRD to sig- nificantly reduce viral HA activity (a) and viral infectivity (b; $\mathrm{p}<$ $0.01 ; n=4$ or more experiments). Free $S$ protein and $S$ proteinbiotin did not enhance the HA-inhibiting activity of hNCRD. Similar results were obtained using rat SP-D NCRD (a). The concentration of hNCRD used in $\mathbf{b}$ was $2 \mu \mathrm{g} / \mathrm{ml}$. 


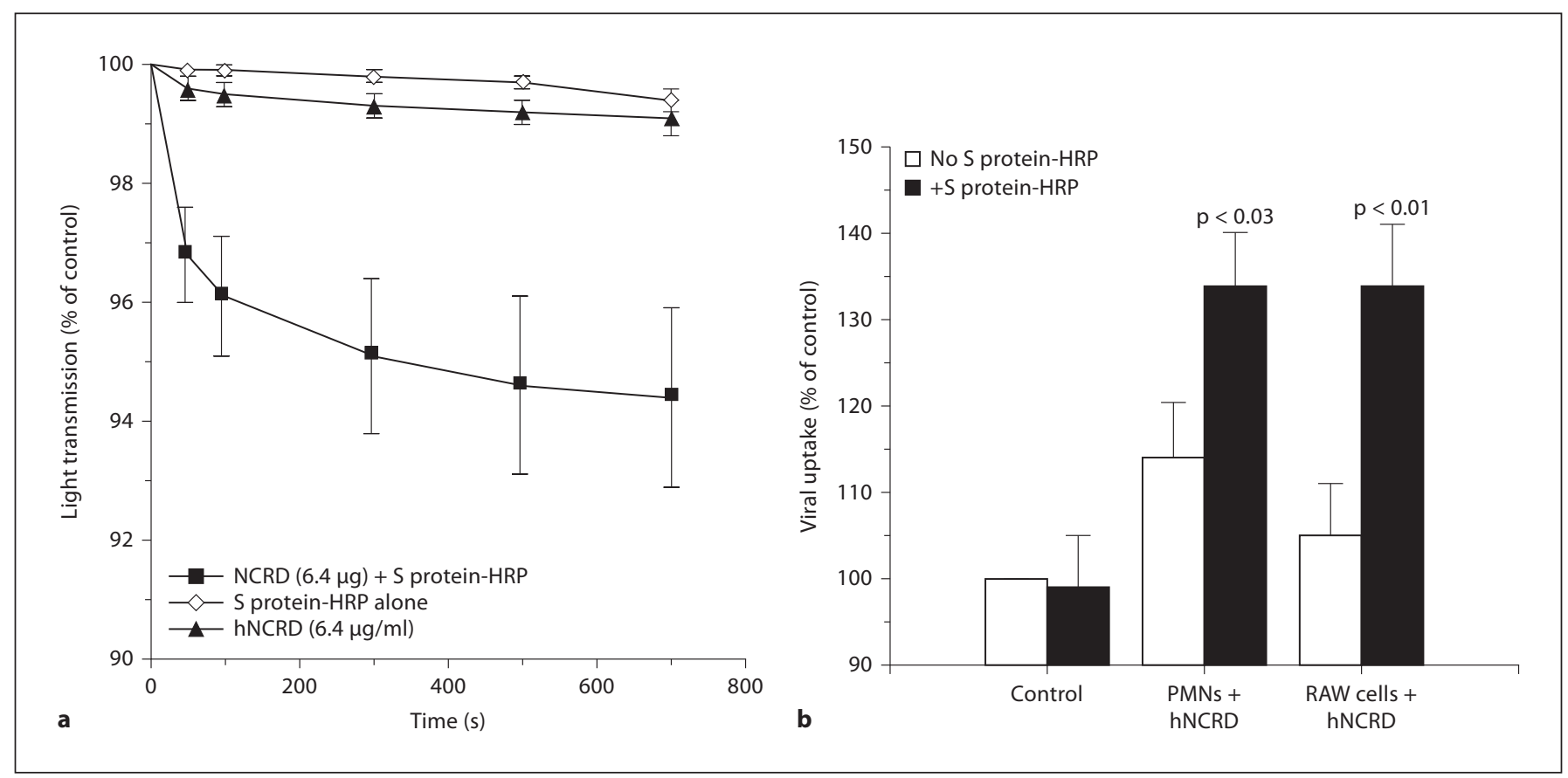

Fig. 5. Addition of S protein-HRP to hNCRD enables it to cause viral aggregation and to increase viral uptake by human neutrophils and RAW 264.7 cells. a Addition of S protein-HRP to hNCRD at the indicated concentration resulted in significant viral aggregation $[\mathrm{p}<0.04$ compared to virus alone (not shown), virus + hNCRD or virus + S protein-HRP; $\mathrm{n}=7$ ]. $\mathbf{b}$ Similarly, addition of S protein-HRP to NCRD $(16 \mu \mathrm{g} / \mathrm{ml})$ resulted in significant increases in viral uptake by neutrophils and RAW cells as compared to hNCRD alone ( $\mathrm{n}=4$ for neutrophils and $\mathrm{n}=8$ for RAW cells). S protein-HRP alone did not alter viral uptake (data not shown). PMNs = Polymorphonuclear cells (neutrophils). c Representative electron microscopic pictures of IAV treated with hNCRD alone or hNCRD $+S$ protein-HRP in the same manner as for the viral uptake assay.

phagocyte uptake assays were analyzed by electron microscopy and showed clear viral aggregation (fig. 5c). S protein-HRP alone (in the absence of NCRD) did not inhibit HA activity or viral infectivity (data not shown) and did not induce viral aggregation (fig. 5a). S protein-HRP alone did not alter viral uptake by phagocytes or result in viral aggregating activity (data not shown).

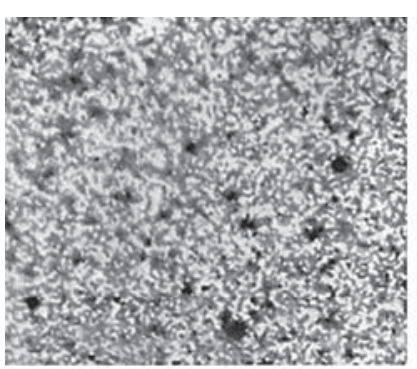

hNCRD $(16 \mu \mathrm{g})$

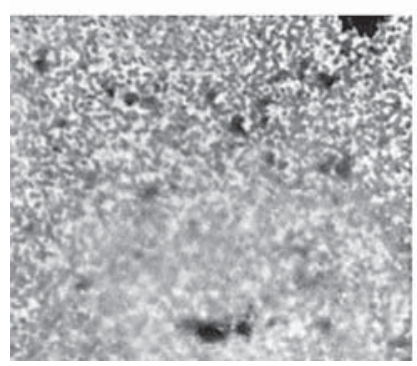

c $\quad \operatorname{hNCRD}(32 \mu \mathrm{g})$

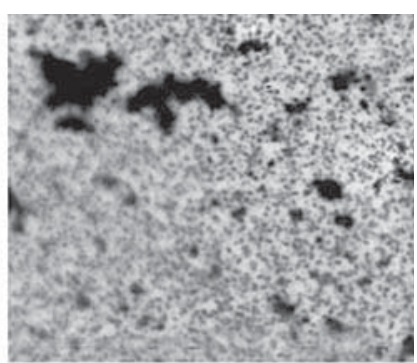

hNCRD $(16 \mu \mathrm{g})+\mathrm{S}$ protein-HRP

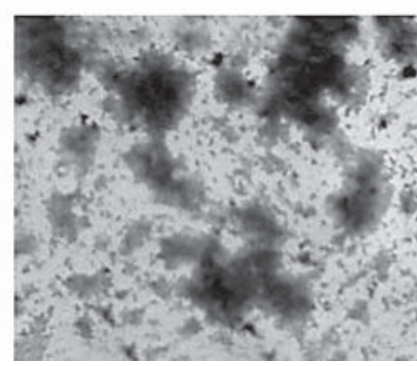

$\mathrm{hNCRD}(32 \mu \mathrm{g})+\mathrm{S}$ protein-HRP

Use of S Protein-HRP to Compare Antiviral Activities of Mammalian Collectin NCRDs after Cross-Linking

In figure 6, we compare the HA-inhibitory activity of several wild-type collectin NCRDs with that of the R343V mutant form of the human SP-D NCRD. As noted, we have reported that the $\mathrm{R} 343 \mathrm{~V}$ mutant form of human NCRD has substantially increased antiviral activity com- 


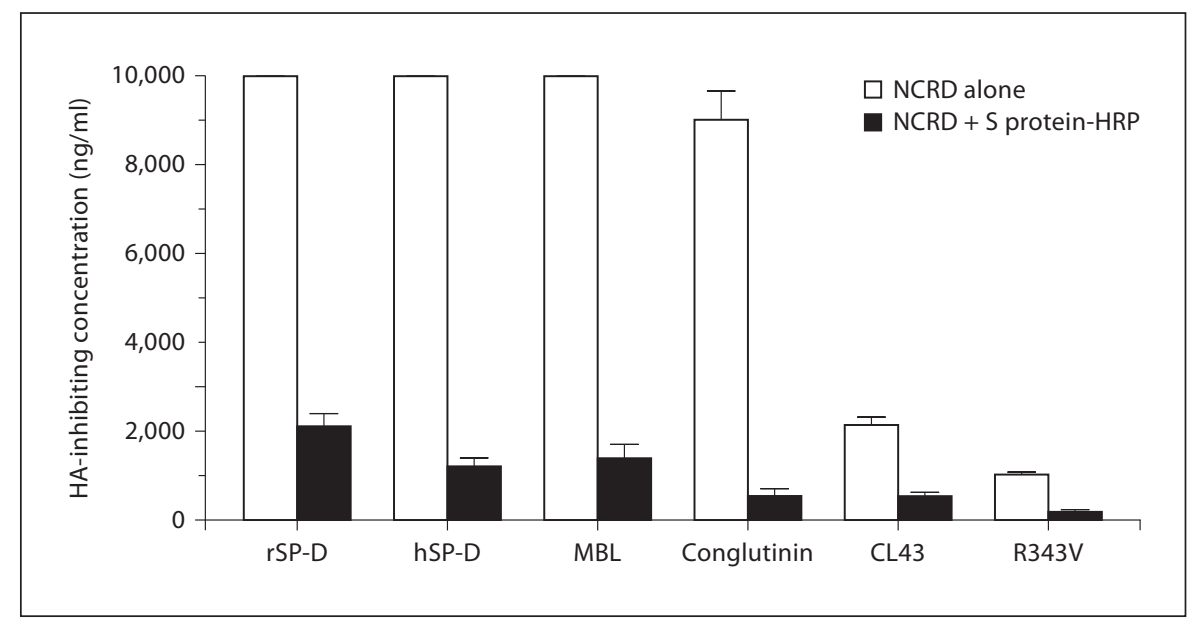

Fig. 6. Addition of S protein-HRP to various collectin NCRDs increases their HA-inhibiting activity. NCRDs derived from human SP-D (hSP-d), rat SP-D (rSP-D) or human MBL did not cause any HA inhibition on their own up to concentrations of $10 \mu \mathrm{g} / \mathrm{ml}$; however, when the NCRDs were preincubated with $S$ proteinHRP, significant HA inhibition occurred $(n=4 ; p<0.04$ for each compared with NCRD alone). The CL43, conglutinin and R343V preparations caused HA inhibition on their own, and this activity was again significantly increased by S protein-HRP. CL43 and conglutinin NCRDs $+S$ protein-HRP caused significantly greater inhibition than SP-D NCRDs $+S$ protein-HRP $(p<0.02)$, and $\mathrm{R} 343 \mathrm{~V}+\mathrm{S}$ protein-HRP caused significantly greater inhibition than any of the other NCRDs. pared to the wild-type hNCRD [13]. The only wild-type NCRDs that had measurable activity in the absence of cross-linking were those of CL43 (as previously reported [12]) and bovine conglutinin. Note that R343V had considerably greater activity than any of the wild-type collectin NCRDs. All the NCRDs contain equivalent S protein binding sites. The HA-inhibitory activity of all of the proteins was significantly increased by $S$ protein-HRP. After cross-linking with $S$ protein-HRP, the following hierarchy of activity was determined: R343V $>$ CL43 or conglutinin $>$ MBL or human SP-D $>$ rat SP-D. NCRDs with intrinsic activity prior to cross-linking had the greatest activity after cross-linking. As above, free S protein or S protein-biotin did not increase the HA-inhibiting activity of R343V (data not shown).

Cross-Linking of a Mutant hNCRD that Has Increased Intrinsic Antiviral Activity Results in Further Increase in Antiviral Activity

Given that $S$ protein-HRP caused a marked increase in the HA-inhibiting activity of R343V, we tested the ability of $\mathrm{mAbs}$ to increase various antiviral activities of R343V and R343I. R343I alone had lower antiviral activity than R343V but significantly greater than wild-type hNCRD in our prior studies [13]. Incubation of R343V with either the 246-04 or 246-08 mAb increased its bind- ing to IAV (fig. 7a). These antibodies also significantly increased the HA-inhibiting activity of R343V and R343I (fig. 7b). This effect was reproduced using $F(a b ') 2$ fragments of the 246-08 mAb (fig. 7c). In contrast, $F(a b ') 1$ fragments significantly reduced the intrinsic HA-inhibiting activity of R343V (fig. 7c). Similarly, the full 246-08 $\mathrm{mAb}$ significantly increased the neutralizing activity of R343V (fig. 7d), whereas the F(ab')1 fragment of this antibody essentially abrogated the neutralizing activity of R343V.

Avian and pandemic viral strains have less glycosylation on their HA than strains that have evolved for years in the human population [27]. Therefore, we wanted to determine whether cross-linking of the R343V construct would have increased activity against a less glycosylated viral strain. For this purpose, we used the Phil82/BS strain, which is derived from the Phil82 strain used in this study but lacks a key oligomannose glycan attachment on the tip of the viral HA [28]. We tested the effects of hNCRD or R343V alone or after cross-linking with $\mathrm{S}$ protein-HRP, the $246-04 \mathrm{mAb}$ or an isotype control (IgG2a) on the HA activity of the Phil82/BS strain. As shown in table 1, both $\mathrm{S}$ protein-HRP and the 246-04 $\mathrm{mAb}$ caused a considerable increase in the activity of R343V against the Phil82/BS strain. This strain was less sensitive to inhibition by cross-linked hNCRD or R343V 


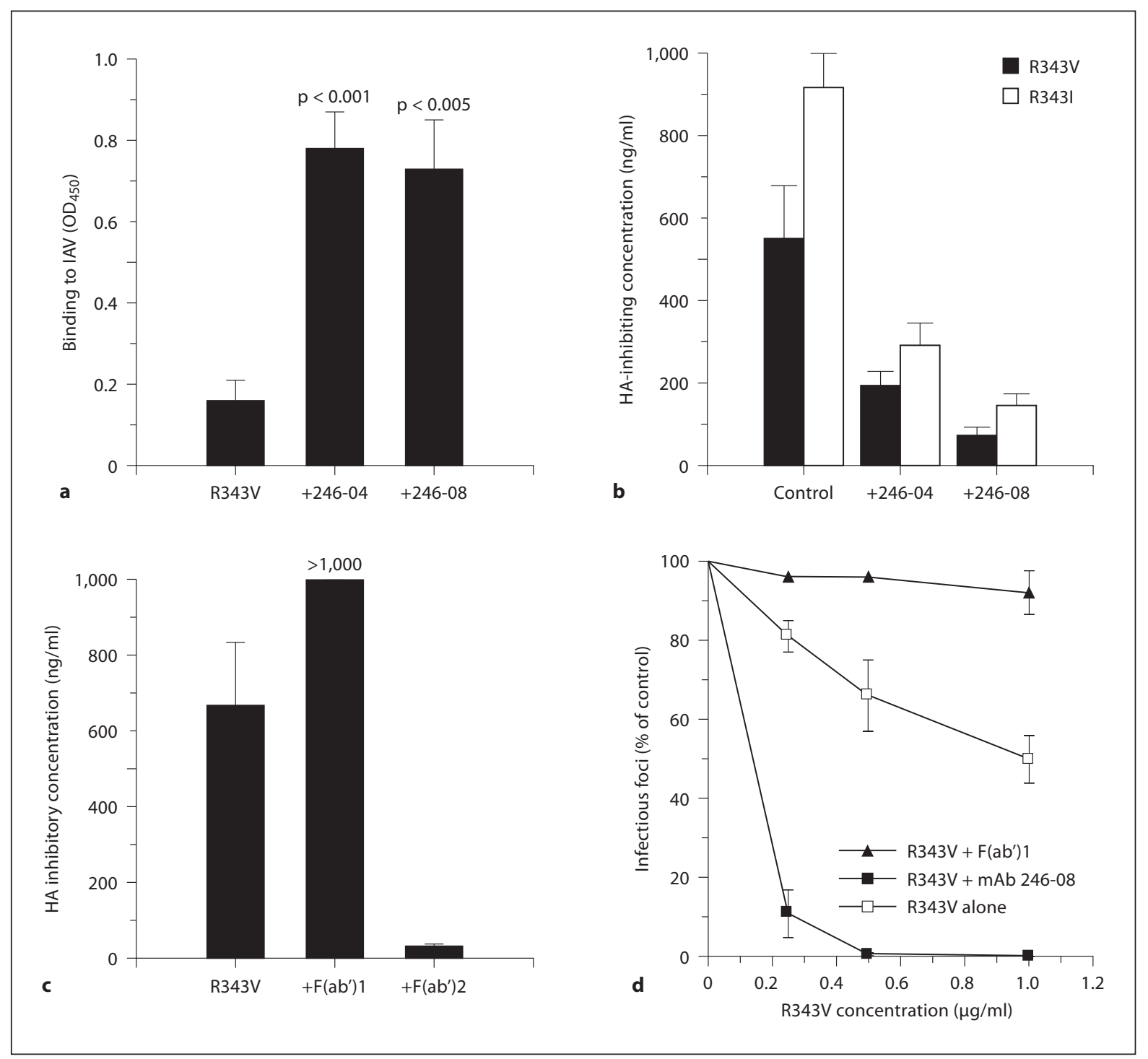

Fig. 7. Effects of mAbs alone or Fab fragments of mAb 246-08 on the ability of R343V to bind to IAV (a), inhibit the HA activity of IAV (b, c) or neutralize IAV (d). a Binding of R343V to IAV was significantly increased as assessed by ELISA $(250 \mathrm{ng} / \mathrm{ml}$ of R343V used; $n=6$ ) when either mAb 246-04 or 246-08 was added. b Similarly, these $\mathrm{mAbs}$ significantly increased the ability of R343V and R343I to inhibit the HA activity of IAV ( $n=4 ; \mathrm{p}<0.05)$. Note that

than the parental Phil82 strain; however, the combination of R343V and either the $\mathrm{mAb}$ or S protein-HRP was inhibitory at nanomolar concentrations of R343V. In contrast, even after cross-linking, $10 \mu \mathrm{g} / \mathrm{ml}$ or more of hNCRD was needed to inhibit this strain. The isotype control antibody did not cause any increase in the activity of either hNCRD or R343V.

Opsonizing Activity of Trimeric Collectins
R343V and R343I have measurable HA-inhibitory activity on their own (unlike the wild-type NCRD). c Addition of F(ab')2 fragments of $\mathrm{mAb}$ 246-08 to R343V significantly increased its HA-inhibiting activity, whereas $\mathrm{F}(\mathrm{ab}) 1$ fragments significantly reduced it $(\mathrm{n}=4$; $\mathrm{p}<0.01$ for both). d Similarly, the intact mAb 246-08 significantly increased the viral neutralizing activity of R343V, whereas the $\mathrm{F}(\mathrm{ab}) 1$ fragments strongly reduced it ( $\mathrm{n}=4$; $\mathrm{p}<0.02$ for both).

\section{Discussion}

Relevance of Findings to Understanding Mechanisms of Antiviral Activity of Collectins

In this study, we established that the ability of mAbs to increase the antiviral activity of either human or rat SP-D NCRDs does not depend on their Fc domain but does require bivalency. The use of $\mathrm{F}(\mathrm{ab}$ ') 2 fragments pro-

J Innate Immun 2010;2:267-279 
Table 1. Effect of cross-linking on HA inhibition of various viral strains by hNCRD and R343V

\begin{tabular}{llllcc}
\hline NCRD & Viral & Control & $+\mathrm{S}$ & $+\mathrm{mAb}$ & + IgG2a isotype \\
& strain & protein-HRP & $246-04$ & control \\
\hline hNCRD & Phil82 & $>20$ & $1.21 \pm 0.3^{*}$ & $10 \pm 0^{*}$ & $>20$ \\
& Phil82/BS & $>20$ & $10 \pm 0^{*}$ & $>20$ & $>20$ \\
R343V & Phil82 & $1.03 \pm 0.3$ & $0.07 \pm 0.01^{*}$ & $0.05 \pm 0.02^{*}$ & $0.9 \pm 0.06$ \\
& Phil82/BS & approx. $20^{1}$ & $0.41 \pm 0.1^{*}$ & $0.46 \pm 0.18^{*}$ & $\sim 20$ \\
\hline
\end{tabular}

Results shown are the amounts of NCRDs in $\mu \mathrm{g} / \mathrm{ml}$ needed to inhibit 40 hemagglutinin units of the indicated viral strains and are means \pm SEM of 4 experiments. The amount of mAb or isotype control used was $1.25 \mu \mathrm{g} / \mathrm{ml}$. * Significant reduction in the concentration needed for inhibition by S protein-HRP or the 246-04 $\mathrm{mAb}$ compared to NCRD alone.

${ }^{1}$ The value is approximately $20 \mu \mathrm{g} / \mathrm{ml}$ because there was variable inhibition at this concentration at the limit of detection of the assay.

vides a minimal model of cross-linking and suggests that the formation of hexamers (i.e. 2 trimers together) can be sufficient for enhancement of viral binding. We reached a similar conclusion in a recent study involving a modified form of rat SP-D lacking one half of the collagen domain [4]. This molecule (called 'mini-SP-D') has increased antiviral and opsonizing activity compared to wild-type rat SP-D and on electron microscopy forms dodecamers in which 2 of the trimeric NCRD heads are adjacent to each other, raising the possibility that a hexameric binding surface may be more easily generated by this form of SP-D.

We utilized S protein-HRP as an alternative means of cross-linking NCRDs. The $S$ protein-HRP conjugate presents $S$ protein in a functionally multivalent manner, whereas free S protein and S protein-biotin do not. These results again show that formation of a multimeric array of hNCRD (or rNCRD) is important for generating antiviral activity since the complexes formed by $S$ proteinHRP resulted in increased viral binding and neutralizing and HA-inhibiting activity compared to NCRD (or S protein-HRP) alone. The monomeric $S$ protein preparations did not have these effects.

\section{Relevance of Findings to Understanding the}

Mechanisms of Viral Opsonizing Activity of SP-D or of

NCRDs Complexed with mAbs

Engagement of Fc receptors on neutrophils or monocytes by various antibody-antigen complexes can increase both phagocytosis of antigens and cell activation as assessed by respiratory burst or other activities. We have previously shown that complexes of antiviral antibodies and IAV particles result in marked potentiation of IAV-induced neutrophil respiratory burst responses [29]. Similarly, Tacken et al. [30] reported similar results using mAbs directed against IAV and a bispecific protein containing hNCRD coupled to a $\mathrm{F}(\mathrm{ab}) 1$ fragment directed against a neutrophil $\mathrm{Fc}$ receptor that are able to simultaneously bind to $\mathrm{Fc}$ receptors and viral particles (through the NCRD domain). We have also shown that preincubation of IAV with full-length SP-D dodecamers markedly potentiates viral uptake by neutrophils and virus-induced respiratory burst responses [21]. We have speculated that these effects result in large part from SP$\mathrm{D}$-mediated viral aggregation $[29,31]$. Another possibility is that the N-terminal and collagen domains of SP-D or other collectins engage specific receptors on phagocytes to trigger phagocytosis and increased cellular activation. For instance, Gardai et al. [32] have shown that such receptors are important for mediating macrophage phagocytosis and activation in response to complexes of SP-D and lipopolysaccharide or apoptotic cell fragments.

We used the Fab fragments and S protein-HRP to assess the role of $\mathrm{Fc}$ receptors in the ability of $\mathrm{mAb} 246-08$ to confer opsonizing activity on the human SP-D NCRD. The wild-type hNCRD had no opsonizing activity on its own. This is similar to our prior finding that full-length trimers of SP-D do not cause viral aggregation or increase neutrophil uptake or respiratory burst responses to IAV [33]. While the $\mathrm{F}\left(\mathrm{ab} \mathrm{b}^{\prime}\right) 2$ was essentially equivalent to the intact $\mathrm{mAb} 246-08$ in increasing the neutralizing and HA-inhibiting activity of hNCRD, it was less active than the $\mathrm{mAb}$ in increasing the opsonizing activity hNCRD. Specifically, cross-linking of the hNCRD with $\mathrm{F}(\mathrm{ab}$ ')2 modestly increased uptake of IAV by neutrophils [and 
$\mathrm{F}(\mathrm{ab}$ ')1 did not]; however, the intact $\mathrm{mAb}$ was considerably more active in this regard. Combination of $\mathrm{F}\left(\mathrm{ab} \mathrm{b}^{\prime}\right) 2$ fragments with the hNCRD also did not enhance neutrophil respiratory burst responses compared to IAV alone. This implies that the Fc domain on mAb 246-08 engages Fc receptors on neutrophils and that this participates in enhancement of viral uptake and $\mathrm{H}_{2} \mathrm{O}_{2}$ generation.

We have now also shown that cross-linking of the human SP-D NCRD results in increased ability to promote uptake by the macrophage-like cell line RAW 264.7. The Fc domain of the mAb did not appear to contribute to enhanced uptake by RAW cells [because $\mathrm{F}(\mathrm{ab}$ ') 2 and the intact $\mathrm{mAb}$ had similar effects]. It may be that differences in Fc receptors between human neutrophils and the murine RAW cells were involved in this effect. In any case, it is noteworthy that cross-linking of the hNCRD also increased uptake by macrophage-like cells. These results suggest that receptors for the N-terminal domains of SP-D are not critical for increasing uptake of IAV by SP-D [i.e. because $\mathrm{F}(\mathrm{ab}$ ') 2 and hNCRD increased uptake].

We also show that cross-linking of SP-D NCRDs with the $S$ protein-HRP complexes allowed the NCRDs to induce viral aggregation and to increase neutrophil and RAW cell uptake of IAV. These findings again suggest that the N-terminal domains of SP-D are not required to potentiate viral uptake by phagocytes as long as viral aggregation occurs.

Use of S Protein-HRP Aggregates to Compare Intrinsic Antiviral Activity of Wild-Type Collectin NCRDs

We have previously shown that chimeric molecules composed of the N-terminal and collagen domains of SP$\mathrm{D}$ and the NCRDs of either MBL or conglutinin have increased antiviral activity compared to wild-type SP-D $[24,34]$. In addition, an NCRD preparation of CL43 had increased activity compared to a similar preparation of SP-D [12]. These findings suggest that the NCRDs of serum collectins have increased intrinsic antiviral activity compared to the SP-D hNCRD. Since not all wild-type NCRDs have measurable activity in the absence of crosslinking, we used the S protein-HRP complexes to potentiate the antiviral activity of a set of wild-type NCRDs all prepared in a similar manner and all containing the $S$ protein binding site. Using this method, we established a hierarchy of activity of wild-type NCRDs as follows: CL43 > conglutinin > SP-D or MBL. It is of interest that the MBL NCRD had roughly equivalent activity to the rat and mouse SP-D NCRDs.

Opsonizing Activity of Trimeric

Collectins

\section{Therapeutic Implications}

We have previously shown that the intrinsic antiviral activity of hNCRD can be greatly increased by specific mutations of residues surrounding the lectin-binding site of the NCRD (as in R343V) [13]. These mutations increase the ability of the hNCRD to bind high-mannose glycans of the type found on the viral HA of recent human strains. We have now demonstrated that the neutralizing activity of R343V can be strongly potentiated by cross-linking with $\mathrm{mAb} 246-08$. The combined effects of the $\mathrm{R} 343 \mathrm{~V}$ mutation and cross-linking result in inhibition of IAV at concentrations of R343V under $100 \mathrm{ng} / \mathrm{ml}$. The activity of R343V cross-linked with S protein-HRP is also notable, since it was greater than the activity of any of the wild-type collectins treated in a similar manner. These results support the concept that combining two methods of increasing the activity of NCRDs (i.e. mutagenesis of the binding region and cross-linking of trimers) can have additive or synergistic effects. Of interest, cross-linking of R343V with either an $\mathrm{mAb}$ or S proteinHRP also caused a marked increase in activity against a hypoglycosylated strain of IAV, suggesting that the combined strategy of mutagenesis of the NCRD and crosslinking could increase activity against pandemic viral strains that have diminished envelope protein glycosylation.

Our findings have potential relevance to therapeutics because NCRDs are relatively easy to produce in large quantities. In addition, the use of collectins without including the collagen domain could be advantageous because the collagen domain is associated with some potential proinflammatory effects of SP-D [32]. The use of S protein-HRP complexes to cross-link NCRDs was more valuable as a tool to evaluate the mechanisms of activity of SP-D than as a potential therapy. In contrast, the use of mAbs or fragments to cross-link NCRDs also has conceivable clinical application because many $\mathrm{mAbs}$ are now being used effectively in the treatment of infectious or inflammatory diseases or cancer. For instance, palivizumab, which is an $\mathrm{mAb}$ directed against the respiratory syncytial virus fusion protein, is effective in prophylaxis against severe infection [35]. This implies that mAbs can achieve significant levels in the lung and inhibit respiratory viral replication. Furthermore, $\mathrm{F}\left(\mathrm{ab} \mathrm{b}^{\prime}\right) 1$ or $\mathrm{F}\left(\mathrm{ab} \mathrm{b}^{\prime}\right) 2$ fragments are also used in treatment. Certolizumab is an $\mathrm{F}\left(\mathrm{ab} \mathrm{b}^{\prime}\right) 1$ fragment of an $\mathrm{mAb}$ directed against tumor necrosis factor alpha that has significant therapeutic benefit in Crohn's disease [36]. In this case, conjugation of the $\mathrm{F}(\mathrm{ab}) 1$ fragment with polyethylene glycol is used to prolong the serum half-life. In animal models, $\mathrm{F}(\mathrm{ab}$ ') 2 frag-

J Innate Immun 2010;2:267-279 
ments directed against the severe acute respiratory syndrome coronavirus or highly pathogenic H5N1 IAV show therapeutic benefit, indicating that such antibody fragments can achieve meaningful levels in the respiratory tract $[37,38]$.

We are not aware of therapies using mAbs or fragments of antibodies to potentiate the activity of endogenous host defense molecules or to combine with therapeutic administered inhibitors (like NCRDs), but testing this approach in mouse models seems plausible. The specific advantage of the use of $\mathrm{F}(\mathrm{ab}$ ')2 fragments to crosslink NCRDs (or possibly endogenous SP-D) is that because they lack the Fc domain, these fragments do not provoke complement activation, antibody-dependent cellular cytotoxicity or respiratory burst activation of neutrophils. There is evidence that reactive oxygen or ni- trogen species are harmful in the context of severe IAV infection $[1,39,40]$, so it could be advantageous to avoid triggering such responses. It is also of specific interest that cross-linking of the NCRD of MBL results in increased antiviral activity without the use of the N-terminal and collagen domains. This could be of therapeutic interest since the $\mathrm{N}$-terminal and collagen domains of MBL mediate complement activation, which could be deleterious in some settings [41, 42].

\section{Acknowledgements}

This work was supported by NIH grants HL069031 (K.L.H.) and AI083222 (K.L.H. and E.C.C.).

\section{References}

1 White M, Doss M, Boland P, Tecle T, Hartshorn K: Innate immunity to influenza virus: implications for future therapy. Expert Rev Clin Immunol 2008;4:497-514.

-2 Crouch E, Wright J: Surfactant proteins A and $\mathrm{D}$ and pulmonary host defense. Annu Rev Physiol 2001;63:521-554.

- 3 Tecle T, White MR, Sorensen G, Gantz D, Kacak N, Holmskov U, Smith K, Crouch EC, Hartshorn KL: Critical role for cross-linking of trimeric lectin domains of surfactant protein $D$ in antiviral activity against influenza A virus. Biochem J 2008;412:323-329.

4 White M, Kingma P, Tecle T, Kacak N, Linders B, Heuser J, Crouch E, Hartshorn K: Multimerization of surfactant protein D, but not its collagen domain, is required for antiviral and opsonic activities related to influenza virus. J Immunol 2008;181:7936-7943.

5 Hartshorn KL, White MR, Tecle T, Tornoe I, Sorensen GL, Crouch EC, Holmskov U: Reduced influenza viral neutralizing activity of natural human trimers of surfactant protein D. Respir Res 2007;8:9.

6 Knudsen L, Ochs M, Mackay R, Townsend P, Deb R, Muhlfeld C, Richter J, Gilbert F, Hawgood S, Reid K, Clark H: Truncated recombinant human SP-D attenuates emphysema and type II cell changes in SP-D deficient mice. Respir Res 2007;8:70.

7 Clark H, Palaniyar N, Hawgood S, Reid KBM: A recombinant fragment of human surfactant protein D reduces alveolar macrophage apoptosis and pro-inflammatory cytokines in mice developing pulmonary emphysema. Ann NY Acad Sci 2003;1010: 113-116.

\section{Clark H, Palaniyar N, Strong P, Edmondson J, Hawgood S, Reid K: Surfactant protein D reduces alveolar macrophage apoptosis in vivo. J Immunol 2002;169:2892-2899. \\ -9 Strong P, Reid K, Clark H: Intranasal deliv- ery of a truncated recombinant human SP-D is effective at down-regulating allergic hy- persensitivity in mice sensitized to allergens of Aspergillus fumigatus. Clin Exp Immunol 2002;130:19-24. \\ 10 Hickling T, Bright $\mathrm{H}$, Wing K, Gower D, Martin S, Sim R, Malhotra R: A recombinant trimeric surfactant protein D carbohydrate recognition domain inhibits respiratory synctitial virus infection in vitro and in vivo. Eur J Immunol 1999;29:3478-3484.}

11 Knudsen L, Wucherpfennig K, Mackay RM, Townsend P, Muhlfeld C, Richter J, Hawgood S, Reid K, Clark H, Ochs M: A recombinant fragment of human surfactant protein D lacking the short collagen-like stalk fails to correct morphological alterations in lungs of SP-D deficient mice. Anat Rec (Hoboken) 2009;292:183-189.

12 Crouch E, Tu Y, Briner D, McDonald B, Smith K, Holmskov U, Hartshorn K: Ligand specificity of human surfactant protein $\mathrm{D}$ : expression of a mutant trimeric collectin that shows enhanced interactions with influenza A virus. J Biol Chem 2005;280:1704617056.

13 Crouch E, Hartshorn K, Horlacher T, McDonald B, Smith K, Cafarella T, Seaton B, Seeberger P, Head J: Recognition of mannosylated ligands and influenza A virus by human surfactant protein D: contributions of an extended site and residue 343 . Biochemistry 2009;48:3335-3345.
14 Hartshorn KL, Collamer M, Auerbach M, Myers JB, Pavlotsky N, Tauber AI: Effects of influenza A virus on human neutrophil calcium metabolism. J Immunol 1988; 141: 1295-1301.

15 Smee DF, Bailey KW, Wong MH, O’Keefe BR, Gustafson KR, Mishin VP, Gubareva LV: Treatment of influenza A (H1N1) virus infections in mice and ferrets with cyanovirinN. Antiviral Res 2008;80:266-271.

16 Hartshorn K, Chang D, Rust K, White M, Heuser J, Crouch E: Interactions of recombinant human pulmonary surfactant protein $\mathrm{D}$ and SP-D multimers with influenza A. Am J Physiol 1996;271:L753-L762.

17 Crouch EC, Smith K, McDonald B, Briner D, Linders B, McDonald J, Holmskov U, Head J, Hartshorn K: Species differences in the carbohydrate binding preferences of surfactant protein D. Am J Respir Cell Mol Biol 2006; 35:84-94.

18 Allen MJ, Laederach A, Reilly PJ, Mason RJ, Voelker DR: Arg343 in human surfactant protein $\mathrm{D}$ governs discrimination between glucose and $\mathrm{N}$-acetylglucosamine ligands. Glycobiology 2004; 14:693-700.

19 Madsen J, Kliem A, Tornoe I, Skjolt K, Koch C, Holmskov U: Localization of lung surfactant protein D on mucosal surfaces in human tissues. J Immunol 2000;164:5866-5870.

20 White MR, Crouch E, van Eijk M, Hartshorn M, Pemberton L, Tornoe I, Holmskov U, Hartshorn KL: Cooperative anti-influenza activities of respiratory innate immune proteins and neuraminidase inhibitor. Am J Physiol Lung Cell Mol Physiol 2005;288: L831-L840. 
-21 Hartshorn KL, Crouch EC, White MR, Eggleton P, Tauber AI, Chang D, Sastry K: Evidence for a protective role of pulmonary surfactant protein $\mathrm{D}$ (SP-D) against influenza A viruses. J Clin Invest 1994;94:311-319.

22 Hartshorn KL, Sastry K, Brown D, White MR, Okarma TB, Lee Y, Tauber AI: Conglutinin acts as an opsonin for influenza A viruses. J Immunol 1993;151:1-9.

23 Tecle T, White MR, Gantz D, Crouch EC, Hartshorn KL: Human neutrophil defensins increase neutrophil uptake of influenza A virus and bacteria and modify virus-induced respiratory burst responses. J Immunol 2007; 178:8046-8052.

-24 Hartshorn K, Sastry K, Chang D, White M, Crouch E: Enhanced antinfluenza activity of a recombinant pulmonary surfactant protein $\mathrm{D}$ and serum conglutinin fusion protein Am J Physiol 2000;278:L90-L98.

25 Hartshorn K, White M, Shepherd V, Reid K, Jensenius J, Crouch E: Mechanisms of antiinfluenza activity of pulmonary surfactant proteins $\mathrm{A}$ and $\mathrm{D}$ : comparison with other collectins. Am J Physiol 1997;273:L1156L1166.

26 Hartshorn KL, Collamer M, White MR, Schwartz JH, Tauber AI: Characterization of influenza A virus activation of the human neutrophil. Blood 1990;75:218-226.

-27 Hartshorn KL, Webby R, White MR, Tecle T, Pan C, Boucher S, Moreland RJ, Crouch EC, Scheule RK: Role of viral hemagglutinin glycosylation in anti-influenza activities of recombinant surfactant protein D. Respir Res 2008;9:65.

28 Hartley CA, Jackson DC, Anders EM: Two distinct serum mannose-binding lectins function as beta inhibitors of influenza virus: identification of bovine serum beta inhibitor as conglutinin. J Virol 1992;66:4358-4363.
29 Hartshorn KL, Reid KB, White MR, Jensenius JC, Morris SM, Tauber AI, Crouch E: Neutrophil deactivation by influenza A viruses: mechanisms of protection after viral opsonization with collectins and hemagglutination-inhibiting antibodies. Blood 1996; 87:3450-3461.

30 Tacken PJ, Hartshorn KL, White MR, van Kooten C, van de Winkel JG, Reid KB, Batenburg JJ: Effective targeting of pathogens to neutrophils via chimeric surfactant protein D/anti-CD89 protein. J Immunol 2004;172: 4934-4940.

31 Hartshorn KL, White MR, Shepherd V, Reid $\mathrm{K}$, Jensenius JC, Crouch EC: Mechanisms of anti-influenza activity of surfactant proteins $\mathrm{A}$ and D: comparison with serum collectins. Am J Physiol 1997;273:L1156-L1166.

32 Gardai S, Xiao Y, Dickinson M, Nick J, Voelker D, Green K, Henson P: By binding SIRP or calreticulin/CD91, lung collectins act as dual function surveillance molecules to suppress or enhance inflammation. Cell 2003;115:13-23.

33 Brown-Augsburger P, Hartshorn K, Chang D, Rust K, Fliszar C, Welgus H, Crouch E: Site directed mutagenesis of Cys 15 and Cys 20 of pulmonary surfactant protein D: expression of a trimeric protein with altered antiviral properties. J Biol Chem 1996;271: 13724-13730.

34 White MR, Crouch E, Chang D, Sastry K, Guo N, Engelich G, Takahashi K, Ezekowitz RA, Hartshorn KL: Enhanced antiviral and opsonic activity of a human mannose-binding lectin and surfactant protein D chimera. J Immunol 2000;165:2108-2115.
35 Morris SK, Dzolganovski B, Beyene J, Sung L: A meta-analysis of the effect of antibody therapy for the prevention of severe respiratory syncytial virus infection. BMC Infect Dis 2009;9:106.

36 Feagan BG, Coteur G, Tan S, Keininger DL, Schreiber S: Clinically meaningful improvement in health-related quality of life in a randomized controlled trial of certolizumab pegol maintenance therapy for Crohn's disease. Am J Gastroenterol 2009;104:1976-1983.

37 Xu Y, Jia Z, Zhou L, Wang L, Li J, Liang Y, Zhao T, Ni B, Wu Y: Evaluation of the safety, immunogenicity and pharmacokinetics of equine anti-SARS-CoV $\mathrm{F}\left(\mathrm{ab}^{\prime}\right)(2)$ in macaque. Int Immunopharmacol 2007;7:18341840.

-38 Lu J, Guo Z, Pan X, Wang G, Zhang D, Li Y, Tan B, Ouyang L, Yu X: Passive immunotherapy for influenza A H5N1 virus infection with equine hyperimmune globulin $\mathrm{F}(\mathrm{ab}) 2$ in mice. Respir Res 2006;7:43.

39 Snelgrove RJ, Edwards L, Rae AJ, Hussell T: An absence of reactive oxygen species improves the resolution of lung influenza infection. Eur J Immunol 2006;36:1364-1373.

40 Akaike T: Role of free radicals in viral pathogenesis and mutation. Rev Med Virol 2001; 11:87-101.

-41 Fidler KJ, Hilliard TN, Bush A, Johnson M, Geddes DM, Turner MW, Alton EW, Klein NJ, Davies JC: Mannose-binding lectin is present in the infected airway: a possible pulmonary defence mechanism. Thorax 2009; 64:150-155.

42 Takahashi K, Ezekowitz RA: The role of the mannose-binding lectin in innate immunity. Clin Infect Dis 2005;41(suppl 7):S440S444. 